KS. JÓZEF KRUKOWSKI

Wydział Prawa Kanonicznego

Uniwersytetu Kardynała Stefana Wyszyńskiego w Warszawie

\title{
PRZEMÓWIENIE WYGLOSZONE NA UNIWERSYTECIE KARDYNAŁA STEFANA WYSZYŃSKIEGO W WARSZAWIE W DNIU 13 CZERWCA 2015 R. PODCZAS KONFERENCJI POŚWIĘCONEJ KARD. ZENONOWI GROCHOLEWSKIEMU
}

Eminencjo, Najdostojniejszy Księże Kardynale, Ekscelencjo, Magnificencjo, Drodzy Przyjaciele!

Mówię przyjaciele, ponieważ wszyscy jesteśmy złączeni przyjaźnią z Księdzem Kardynałem Grocholewskim w dążeniu do poznania prawdy o tym, jak jest, i jak powinno być, oraz w przykazywaniu prawdy młodemu pokoleniu. Bardzo dziękuję organizatorom dzisiejszego spotkania za zaproszenie na dzisiejszą konferencję. Dołączając się do wypowiedzi znakomitych prelegentów, pragnę - w imieniu własnym i Stowarzyszenia Kanonistów Polskich - wyrazić szczególne uznanie i głęboką wdzięczność Księdzu Kardynałowi, za to, że od ponad 25 lat uczestniczy w naszych konferencjach, podczas których dzieli się z nami swoją wiedzę i mądrością.

Nasze uznanie dla osiągnięć Księdza Kardynała nie jest czymś wyjątkowym. Wskazują na to fakty. Już jako student otrzymał od papieża Pawła VI za rozprawę doktorską na Wydziale Prawa Kanonicznego Papieskiego Uniwersytetu Gregorianum w Rzymie złoty medal jako najwyższe wyróżnienie. Był to bardzo dobry początek. Obecnie jest bowiem laureatem 22 doktoratów honoris causa, nadanych przez uczelnie kościelne i państwowe na kontynencie - europejskim, amerykańskim, afrykańskim i azjatyckim. Otrzymał także 
szereg wysokich odznaczeń kościelnych i państwowych, m.in. Order Orła Białego od Prezydenta RP. Postaram się zwrócić uwagę tylko na Jego najistotniejsze osiągnięcia.

Rację tak wysokiego uznania dla osoby Kard. Grocholewskiego stanowi Jego działalność w Kurii Rzymskiej, zespole organów władzy wspomagających Papieża w realizacji misji prymacjalnej w Kościele i w świecie, oraz bogaty dorobek naukowy. Sprawował bowiem urząd: prefekta Najwyższego Trybunału, czyli przewodniczącego Najwyższego organu władzy sądowniczej w Kościele katolickim; a następnie - prefekta Kongregacji Edukacji Katolickiej, której podlegają wszystkie uniwersytety kościelne i katolickie oraz wydziały teologiczne i seminaria duchowne na całej kuli ziemskiej. Był również przewodniczącym bądź członkiem szeregu specjalnych komisji papieskich, zwłaszcza legislacyjnych.

Działalność dydaktyczną na poziomie uniwersyteckim prowadził na Papieskim Uniwersytecie Gregorianum i na Papieskim Uniwersytecie Lateranum oraz Studium Rotalnym w Rzymie. Wygłaszał referaty podczas kongresów i konferencji międzynarodowych i krajowych w czterdziestu kilku państwach ( $w$ wielu $\mathrm{z}$ nich wielokrotnie), a mianowicie we: Włoszech, Polsce, Francji, Niemczech, Holandii, Austrii, Hiszpanii, Szwajcarii, Słowacji, Republice Czeskiej, Malcie, Węgrach, Rumunii, Chorwacji, Albanii, Bośni i Hercegowinie, Serbii, Rosji, Białorusi, Ukrainie, Kanadzie, Stanach Zjednoczonych Ameryki Północnej, Brazylii, Argentynie, Kolumbii, Chile, Wenezueli, Republice Dominikańskiej, Tajwanie, Tajlandii, Filipinach, Indiach, Libanie, Republice Demokratycznej Kongo, Angoli, Kenii, Kamerunie.

Zapewne trudno jest - nawet wśród kardynałów - znaleźć drugiego człowieka, który potrafił tak jak Kard. Z. Grocholewski łączyć działalność organizacyjną z bardzo intensywną pracą naukowo-badawczą, której rezultatem jest ponad tysiąc pozycji opublikowanych w kilkudziesięciu językach ${ }^{1}$. W Jego dorobku naukowym można

\footnotetext{
${ }^{1}$ Zob. wykaz publikacji Z. Grocholewskiego w: Kardynał Zenon Grocholewski, Umiłowanie Boga - najwyższą mądrością. Nagroda im. Księdza Idziego Radziszewskiego, Towarzystwo Naukowe KUL, Lublin 2013.
} 
wyróżnić szereg wątków, które należą do różnych dyscyplin naukowych. W ich rozwoju można wyróżnić dwa etapy.

Na pierwszym etapie publikacje kard. Grocholewskiego dotyczyły prawa małżeńskiego i prawa procesowego, a zwłaszcza procesu administracyjnego w Kościele po Soborze Watykańskim II, w szczególności problematyki przywróconej przez papieża Pawła VI sądowej kontroli nad działalnością administracyjną w Kościele, sprawowanej za pośrednictwem drugiej sekcji Sygnatury Apostolskiej w celu ochrony praw wiernych w Kościele oraz zapewnienia bardziej obiektywnego, bezstronnego i sprawiedliwego aniżeli w trybie administracyjnym rozstrzygania sporów między wiernymi, jako adresatami aktów administracyjnych, a biskupami, jako autorami tychże aktów, z tytułu nielegalności. Kard. Zenon Grocholewski łączył po mistrzowsku pracę w Najwyższym Trybunale Sygnatury Apostolskiej z działalnością naukową. Dzięki temu stał się jednym z największych autorytetów naukowych w dziedzinie prawa kanonicznego.

Drugi etap nastąpił po objęciu urzędu prefekta Kongregacji Edukacji Katolickiej. W zakres swoich zainteresowań badawczych włączył on problemy dotyczące: aksjologii i filozofii prawa; roli uniwersytetów, w szczególności uniwersytetów katolickich, wydziałów teologicznych i seminariów duchownych.

Przede wszystkim podjął „poszukiwanie wartości leżących u podstaw prawa i moralności, które Kościół wypracował zwłaszcza w odniesieniu do współczesnej kultury”. W kontekście aksjologii prawa zwrócił uwagę na problematykę prawa naturalnego we współczesnym świecie dotkniętym kryzysem wartości, zaistniałym pod wpływem pozytywistycznej filozofii prawa, opartej na relatywizmie etycznym. Prawo naturalne wpisane w serca ludzi - Jego zdaniem - należy „do wielkiego dziedzictwa mądrości ludzkiej, a jednocześnie stanowi przedmiot nauczania Kościoła, bo choć jest podstawową prawdą porządku naturalnego, to oświecone jest światłem Objawienia”. Prawda o prawie naturalnym w świecie współczesnym powinna stanowić podstawę dialogu między katolikami i ludźmi o innych przekonaniach światopoglądowych. 
Kard. Grocholewski wykazuje, że prawo naturalne bynajmniej nie jest wymysłem Kościoła, gdyż począwszy od starożytności greckiej i rzymskiej przewija się przez wszystkie epoki historyczne aż do epoki współczesnej. Przyczyna współczesnego kryzysu prawa naturalnego Jego zdaniem - tkwi w charakterystycznym dla epoki współczesnej kryzysie metafizyki i mentalności nastawionej wyłącznie na poznanie empiryczne. Należy zauważyć, iż tzw. „drugie odrodzenie prawa naturalnego", jakie zaistniało po II wojnie światowej, oraz zastosowanie go w ustawodawstwie międzynarodowym i krajowym, dotyczącym ochrony praw człowieka, współcześnie uległo znacznemu osłabieniu pod wpływem relatywizmu etycznego. Kard. Grocholewski apeluje o „trzecie odrodzenie prawa naturalnego" w ujęciu personalistycznym. Wykazuje, iż współczesna ochrona godności osoby ludzkiej i praw człowieka ma fundament w trwałych wartościach ludzkich, istniejących obiektywnie niezależnie od zmiennych opinii subiektywnych. Ludzie powinni dążyć do głębszego poznawania prawdy o prawie naturalnym. Prawda o prawie naturalnym zawiera podstawowe nakazy ludzkiego postępowania, nacechowane powszechnością i niezmiennością. Prawo naturalne stanowi podstawę porządku moralnego i powinno stanowić podstawę porządku prawnego stanowionego przez władze państwowe w skali krajowej i międzynarodowej.

W punkcie wyjścia w konstruowaniu filozofii prawa Kard. Grocholewski analizuje przesłanki filozofii człowieka - zawarte w encyklikach i innych wypowiedziach Jana Pawła II. Na ich podstawie stwierdza, że w oparciu o prawdę o człowieku należy zająć krytyczne stanowisko wobec współczesnych błędnych tendencji do kwestionowania: prawa człowieka do życia przez wprowadzenie aborcji, prawdy o małżeństwie i rodzinie przez wprowadzanie „małżeństw między osobami tej samej płci” i praktykowania eutanazji.

Publikacje Kard. Zenona Grocholewskiego dotyczą problematyki aktualnej. W epoce pluralizmu światopoglądowego trzeba dążyć do poznania prawdy o człowieku, prawdy o jego godności osobowej i do ochrony należnych mu praw i wolności na drodze dialogu ze wszystkimi ludźmi dobrej woli - na fundamencie prawdy obiektywnej o powszechnie obowiązującym prawie naturalnym. 
W publikacjach poświęconych filozofii - Kard. Grocholewski konstruuje personalistyczną filozofię prawa. Oryginalność Jego rozumowania polega na wskazaniu podstawowych pojęć i zasad filozofii prawa, do których należą: 1) pojęcie człowieka jako osoby, będącej podmiotem działań, skierowanych do prawdy i do dobra; osoby, która się realizuje lub degraduje w swym dobrowolnym działaniu; 2) społeczny wymiar osoby ludzkiej, znajdujący wyraz w partycypacji.

Oryginalność myśli filozoficznej Karola Wojtyły - zdaniem Grocholewskiego - mająca wielkie znaczenie dla filozofii prawa, polega na wskazaniu partycypacji osoby ludzkiej w osiąganiu dobra wspólnego wraz z innymi osobami. Teoria partycypacji w opozycji zarówno do indywidualizmu jak i do totalitaryzmu postuluje zasadę solidarności w dążeniu do osiągnięcia dobra wspólnego osoby ludzkiej. W studium „Filozofia prawa według Jana Pawła II” opartym na analizie encyklik społecznych: „Redemptor hominis” (1979 r.), „Laborem exercens” (1981 r.) i „Sollicitudo rei socialis” (1987 r.).

Kard. Grocholewski wnioskuje, że sama filozofia prawa nie wystarcza, ale powinna być uzupełniona przez teologię prawa. Inaczej mówiąc, poznanie prawd oparte na rozumie naturalnym powinno być uzupełnione przez poznanie prawd zaczerpniętych z Objawienia. Jest to kierunek poznawania rzeczywistości charakterystyczny dla nauczania Jana Pawła II, który w późniejszym zakresie jest zaprezentowany w encyklice „Fides et ratio”.

Drugi wątek problemowy w publikacjach kard. Zenona Grocholewskiego dotyczy roli uniwersytetów i zadań teologii, rozpatrywanych w kontekście współczesnych relacji między Magisterium biskupów a nauczaniem teologów. W publikacjach dotyczących roli uniwersytetów podejmuje trudne problemy, przed jakimi stoją dzisiejsze uniwersytety w skali globalnej, w tym także uniwersytety katolickie i kościelne, oraz wydziały teologiczne i seminaria duchowne. Ustosunkowując się do zjawiska kryzysu uniwersytetów stawia pytanie: czy współczesne uniwersytety mają - zgodnie ze swoją tradycją - pełnić funkcję wspólnoty profesorów i studentów w poznawaniu prawdy w stopniu odpowiadającemu współczesnemu rozwojowi nauki i wychowywaniu ludzi w poszanowaniu podstawowych wartości; 
czy mają stać się tylko przedsiębiorstwami produkującymi specjalistów. Stanowisko kard. Grocholewskiego, jako prefekta Kongregacji Edukacji Katolickiej, było adresowane do ludzi odpowiedzialnych za organizację i poziom edukacji na wszystkich uniwersytetach i w wyższych seminariach duchownych.

Trzeci wątek w publikacjach Kard. Grocholewskiego dotyczy działalności ustawodawczej papieża Jana Pawła II. W studium „Jan Paweł II jako ustawodawca”. Jego zdaniem, pod którym można podpisać się bez zastrzeżeń, Jan Paweł II wszedł do historii ustawodawstwa Kościoła katolickiego jako ten, który dokonał kodyfikacji całego ustawodawstwa kościelnego, obejmującej: „Kodeks Prawa Kanonicznego” dla Kościoła łacińskiego (1983), „Kodeks Kanonów Kościołów Wschodnich” (1990) i Konstytucję Apostolską „Pastor bonus” o reformie Kurii Rzymskiej (1988).

Szanowni Państwo, dorobek naukowy zawarty w publikacjach kard. Grocholewskiego wyróżniający się uniwersalnym zasięgiem - zasługuje na głębsze poznanie i szersze oddziaływanie na mentalność współczesnych filozofów, teologów prawników i polityków.

Szczególną wdzięczność pragnę wyrazić Mu za udział w naszych konferencjach i wypowiedź „Katolicy w życiu politycznym”, zamieszczoną w publikacji zbiorowej na temat „Katolickie zasady relacji państwo-Kościół a prawo polskie"2 (red. J. Krukowski, M. Sitarz, H. Stawniak, Lublin 2015), któremu była poświęcona konferencja naukowa prawników i politologów, zorganizowana na naszej uczelni 20 maja br. Publikacja ta może stać się podstawą dialogu między polskimi prawnikami i politykami w budowaniu lepszej przyszłości.

Eminencjo, przyjmij tę publikację jako wyraz naszej głębokiej wdzięczności za Twój imponujący wkład do dobra wspólnego w dziedzinie edukacji w duchu humanizmu chrześcijańskiego.

\footnotetext{
${ }^{2}$ Katolickie zasady relacji państwo - Kościół a prawo polskie, red. J. Krukowski, M. Sitarz, H. Stawniak, Towarzystwo Naukowe KUL, Lublin 2015.
} 